\title{
Production and movement of branching agent in poinsettia leaf and stem ${ }^{1}$
}

\author{
Gerardo Ruiz-Sifre", John M. Dole ${ }^{3}$ and Brian A. Kahn \\ ABSTRACT
}

Euphorbia pulcherrima Willd. ex. Klotzsch 'Eckespoint C-1 Red' (C-1) a restricted-branching cultivar and ' $\mathrm{CB}$ ' a free-branching vegetative or grafthybrid, were homo and heterografted. Length and number of axillary shoot nodes of $\mathrm{C}-1$ receiver plants (plants which may receive the branching agent from the donor plants) were partially increased by $C B$ donors with leaves removed and with apical and basal parts removed. Shading of $C B$ donors partially increased the length of axillary shoots and the number of axillary shoot nodes of $\mathrm{C}-1$ receivers above node 4 . Production and movement of the branching agent may occur in and go from both stems and leaves of $C B$ poinsettia donors to $\mathrm{C}-1$ poinsettia receivers. Shading $\mathrm{CB}$ donor leaves and stems did not prevent the production and movement of the branching agent to $\mathrm{C}-1$ receivers.

Key words: Euphorbia pulcherrima, apical dominance, axillary-branching, free-branching, restricted-branching

\section{RESUMEN}

Producción y movimiento del agente ramificador en la hoja y el tallo de la pascua

Euphorbia pulcherrima Willd. ex. Klotzsch 'Eckespoint C-1 Red' (C-1), un cultivar de ramificación restringida, y ' $\mathrm{CB}$ '; un ramificador libre o hibrido vegetativo se auto y heteroinjertaron. Los donantes CB con las hojas removidas y con las partes apicales y basales removidas aumentaron parcialmente el número de nudos y el largo de los brotes axilares de la planta recibidora C-1 (planta que puede recibir el agente ramificador de la planta donante). El donante $\mathrm{CB}$ bajo sombra, aumentó parcialmente el número de nudos y el largo de los brotes axilares del recibidor $\mathrm{C}-1$ después del nudo 4 . El agente ramificador se puede producir en, y mover a través de, los tallos y las hojas de las pascuas donantes $\mathrm{CB}$ a las pascuas recibidoras $\mathrm{C}-1$. Sombrear las hojas y los tallos de los donantes $\mathrm{CB}$ no evitó la producción y el movimiento del agente ramificador a los recibidores $\mathrm{C}-1$.

\section{INTRODUCTION}

Today most commercial poinsettias grown are free-branching cultivars, which have weak apical dominance and relatively small stem

'Manuscript submitted to Editorial Board 16 March 1995.

Assistant Researcher, Department of Horticulture.

${ }^{3}$ Associate Professor, Department of Horticulture and Landscape Architecture, Oklahoma State University, Stillwater, OK 74078.

"Professor, Department of Horticulture and Landscape Architecture, Oklahoma State University, Stillwater; OK 74078. 
diameters. Free-branching cultivars include Annette Hegg, Gutbier V-10 and Gutbier V-14 series and are preferred by growers because they allow production of numerous axillary shoots and cuttings per plant when pinched. Less frequently grown are restricted-branching cultivars, such as the Eckespoint C-1 series, which have strong apical dominance, large stem diameters and few axillary shoots when pinched.

The free-branching trait in 'Annette Hegg Brilliant Diamond' (AHBD) can be induced in the restricted-branching 'Eckespoint C-1 Red' (C-1) poinsettia through grafting (Dole and Wilkins, 1992; 1991). The free-branching agent moves both acropetally and basipetally through the graft union and can be serially transmitted from plant to plant by grafting (Dole and Wilkins, 1992). CB (TR), a vegetative or graft-hybrid, was derived from grafting C-1 on to AHBD (Dole and Wilkins, 1992). Vegetative hybridization is the process of grafting two plants together in order to obtain a unique phenotype from the grafted plant itself. Thus, the presence of the agent in CB makes it different from $\mathrm{C}-1$.

In the leaves or stems of free-branching poinsettias may be present an agent that moves through the graft union to a restricted-branching poinsettia's axillary buds. Plant leaves play a role in graft movement of substances that can alter the characteristics of the plants being grafted. Differences in dry weight and starch accumulation in grafted leaves of Nicotiana tabacum L. 'Burley' and 'Flue-Cured' plants were controlled by biochemical or physical factors within an individual leaf (Craft-Brander et al., 1988).

The production and movement of the branching agent from CB donors (plants which may contain and move the branching agent to receiver plants) to $\mathrm{C}-1$ receivers may occur concomitantly with the photosynthate movement from $\mathrm{CB}$ (the source) to $\mathrm{C}-1$ (the sink). Translocation of photosynthates from the rootstock to the scion buds has been demonstrated (Beeson and Proebsting, 1988). Interaction of photosynthates with scion buds may alter the plant's characteristics. Heterografting of Solanum tuberosum L. 'Sable' onto S. tuberosum 'Selection F58050' stock resulted in a slight increase in reducing sugar and a reduction of tuber specific gravity as compared to that of tubers from autografts of ' $F 58050$ ' (Tai et al., 1988), thus indicating that materials from both scions (receivers) and stocks (donors) may control the expression of tuber traits. Stimart's (1983) research on poinsettia grafts between self-branching (free-branching) and non-branching (restricted-branching) cultivars suggested that axillary growth is governed by some endogenous factors translocated from the roots 
across the graft union to the shoots. Interaction between the stock (donor) of $\mathrm{CB}$ and scion (receiver) of C-1 may control movement of photosynthates and the branching agent in $\mathrm{C}-1$.

This research was conducted to further characterize the freebranching agent in poinsettia by determining which organs (stems or leaves) of the free-branching poinsettia contain or produce the agent and whether shading the donor stems and leaves prevents the production and movement of the branching agent.

\section{MATERIALS AND METHOOS}

\section{Leaf removal experiments}

1990. Cuttings from $\mathrm{C}-1$ and $\mathrm{CB}$ poinsettia plants were treated with 1\% IBA (Indole-3-Butyric Acid, Hormex Powder \#1, Brooker Chemical, North Hollywood, $\mathrm{CA})^{5}$ and planted in oasis rootcube growing medium (Smithers-Oasis, Kent, OH) 28 May 1990. After rooting under intermittent mist with a temperature of $21^{\circ} \mathrm{C}$, plants were placed in $16.5-\mathrm{cm}$ $\left(1,650 \mathrm{~cm}^{3}\right)$ pots filled with a commercial peat-based medium (Fafard \#2, Springfield, MA) 27 June 1990. Plants were approach grafted (Hartmann et al., 1990) 22 to 25 August 1990 and placed in a completely randomized design with a $2 \times 2$ factorial arrangement of treatments. Factor A was the $\mathrm{CB}$ and $\mathrm{C}-1$ cultivars as the donor of the grafted pair (donor), and factor $\mathrm{B}$ was the $\mathrm{CB}$ and $\mathrm{C}-1$ cultivars as the receiver of the grafted pair (receiver). Donor leaves were removed 30 days after grafting and periodically thereafter. CB and C-1 plants (donors and receivers) were pulled apart 40 days after grafting. Six single unit replicates were used for each treatment.

Vegetative growth was maintained by supplementary incandescent and high-intensity-discharge lamps to provide long (LD) photoperiods of $15 \mathrm{~h}$. Light intensity averaged $780 \mu \mathrm{mol} / \mathrm{m}^{2} / \mathrm{sec}$ of photosynthetically active radiation (PAR) during daylight hours. Air temperature in the greenhouse was kept at an average $31^{\circ} / 21^{\circ} \mathrm{C}$ day/night. Standard fertilization and pest management practices were used (Ecke et al., 1990).

Poinsettia receiver plants were pinched back to the 12 th node when plants developed at least 12 nodes above the graft union. Thirty days after pinching, data were taken on the receiver of each grafted pair. The number of nodes with leaves (including the terminal leaf blade separated from the apical cone) was determined and the length was

\footnotetext{
"Trade names in this publication are used only to provide specific information. Mention of a trade name does not constitute a warranty of materials by the UPR/AES, nor is this mention a statement of preference over other materials.
} 
measured from the base of each axillary shoot to the tip of the apical cone.

1990-1991. Similar materials and methods and the same treatments as in 1990 were used except that plants were propagated 27 August 1990, planted 28 September 1990 and approach grafted 5 to 7 December 1990. In this study poinsettia donor leaves were periodically removed beginning seven days after grafting, and $\mathrm{CB}$ and/or $\mathrm{C}-1$ plants were pulled apart 30 days after grafting. Six single unit replicates were used for each treatment.

Stem removal experiments

Materials and methods and factorial arrangement of treatments used were similar to those in leaf removal and performed simultaneously with the leaf experiments. In factor $B$, the apical and basal parts of poinsettia donor stems were removed 30 days after grafting in 1990 and 15 days after grafting in 1990-1991 and 1991. Ten single unit replicates were used for each treatment in 1990, six in 1990-1991, and 12 in 1991. The 1991 trial was done at the Noble Research Center Growth Chambers, Stillwater, OK, where vegetative growth was maintained by incandescent and fluorescent lamps from 0800 to $2200 \mathrm{~h}$. Light intensity was maintained at $210 \mu \mathrm{mol} / \mathrm{m}^{2} / \mathrm{sec}$ PAR from 30 September 1991 to 15 November 1991 and reduced to $125 \mu \mathrm{mol} / \mathrm{m}^{2} / \mathrm{sec} \mathrm{PAR}$ from 16 November 1991 to 16 December 1991 to prevent light blanching of the leaves. Air temperature was kept at $26^{\circ} / 18^{\circ} \mathrm{C}$ day/night.

Shade experiment

Materials and methods similar to those in the 1990 leaf experiment were used, except that $\mathrm{CB}$ and $\mathrm{C}-1$ poinsettia plants were propagated 3 October 1991 and planted 16 November 1991. Plants were approach grafted 5 to 20 April 1992 and placed in a completely randomized design with a $2 \times 2 \times 2$ factorial arrangement of treatments. Factor $A$ was the $\mathrm{CB}$ and $\mathrm{C}-1$ cultivars as the donor of the grafted pair (donor); factor $\mathrm{B}$ was placement of donors under shade (95\%, black polypropylene fabric, double layer) or no shade; factor $\mathrm{C}$ was $\mathrm{CB}$ and $\mathrm{C}-1$ cultivars as the receiver of the grafted pair (receiver). Twelve single unit replicates were used for each treatment. Replications were divided into two blocks on one bench, alternating shade and no shade treatments. Black plastic was placed between the shaded donor and the unshaded receiver to isolate one treatment from the other. Light intensity averaged $577 \mu \mathrm{mol} / \mathrm{m}^{2} / \mathrm{sec}$ PAR (unshaded side) and $15 \mu \mathrm{mol} / \mathrm{m}^{2} / \mathrm{sec}$ PAR (shaded side) during daylight hours. Supplementary incandescent light during the night (2000-0200 h) with an intensity of $2.5 \mu \mathrm{mol} / \mathrm{m}^{2} / \mathrm{sec}$ PAR (un- 
shaded side) and $0.8 \mu \mathrm{mol} / \mathrm{m}^{2} / \mathrm{sec}$ PAR (shaded side) was used for all treatments to keep the plants vegetative.

\section{RESULTS AND DISCUSSION}

Leaf removal experiments

Plants from all graft combinations produced similar axillary shoot growth for nodes 10 to 12 in 1990 (Figures 1 and 2). However, for CB/ $\mathrm{CB}$ and $\mathrm{CB} / \mathrm{C}-1$ plants the length of axillary shoots and the number of axillary shoot notes decreased from node 1 to node 9 in 1990. In contrast, C-1/CB axillary shoot growth increased from node 1 to 10 in 1990 (Figures 1 and 2).

$\mathrm{CB}$ donors with leaves removed slightly increased the branching of C-1 receivers for nodes 1-9 compared to branching of C-1/C-1 in 1990 (Figures 1 and 2). Leaves were periodically removed from $\mathrm{CB}$ donors beginning 30 days after grafting. The agent in $\mathrm{CB}$ donor leaves may have been moved to $\mathrm{C}-1$ receivers, thus altering their branching pattern within those 30 days. In 1990-1991, leaves were periodically removed from $\mathrm{CB}$ donors beginning seven days after grafting, and the C-1 receivers branching pattern was slightly altered (Figures 1 and 2).

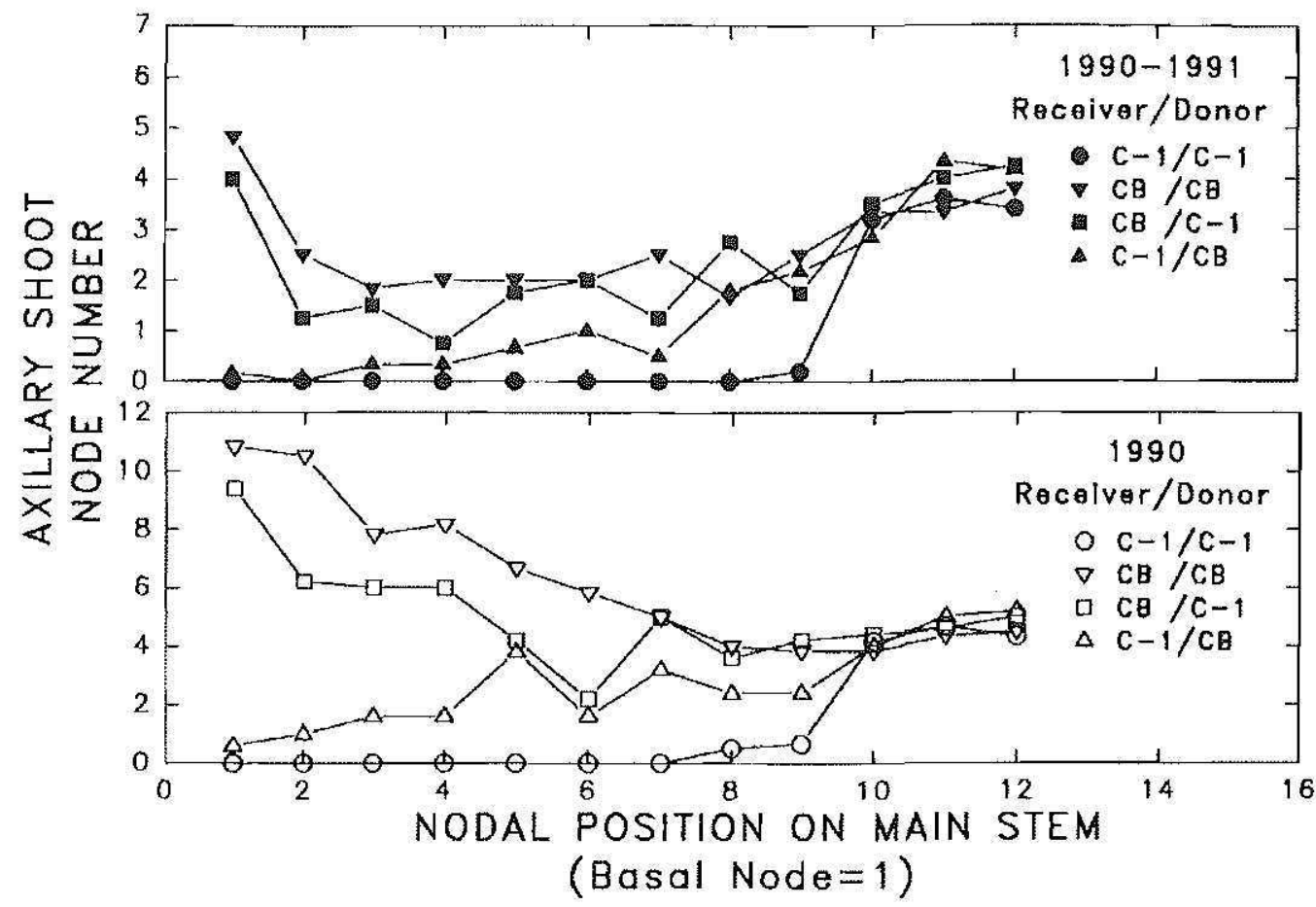

FIGURE 1. Axillary shoot node number of $\mathrm{CB}$ and $\mathrm{C}-1$ poinsettia receivers after grafting on CB and C-1 donors with leaf removal in 1990 and 1990-1991. Means were an average of data from six plants. 


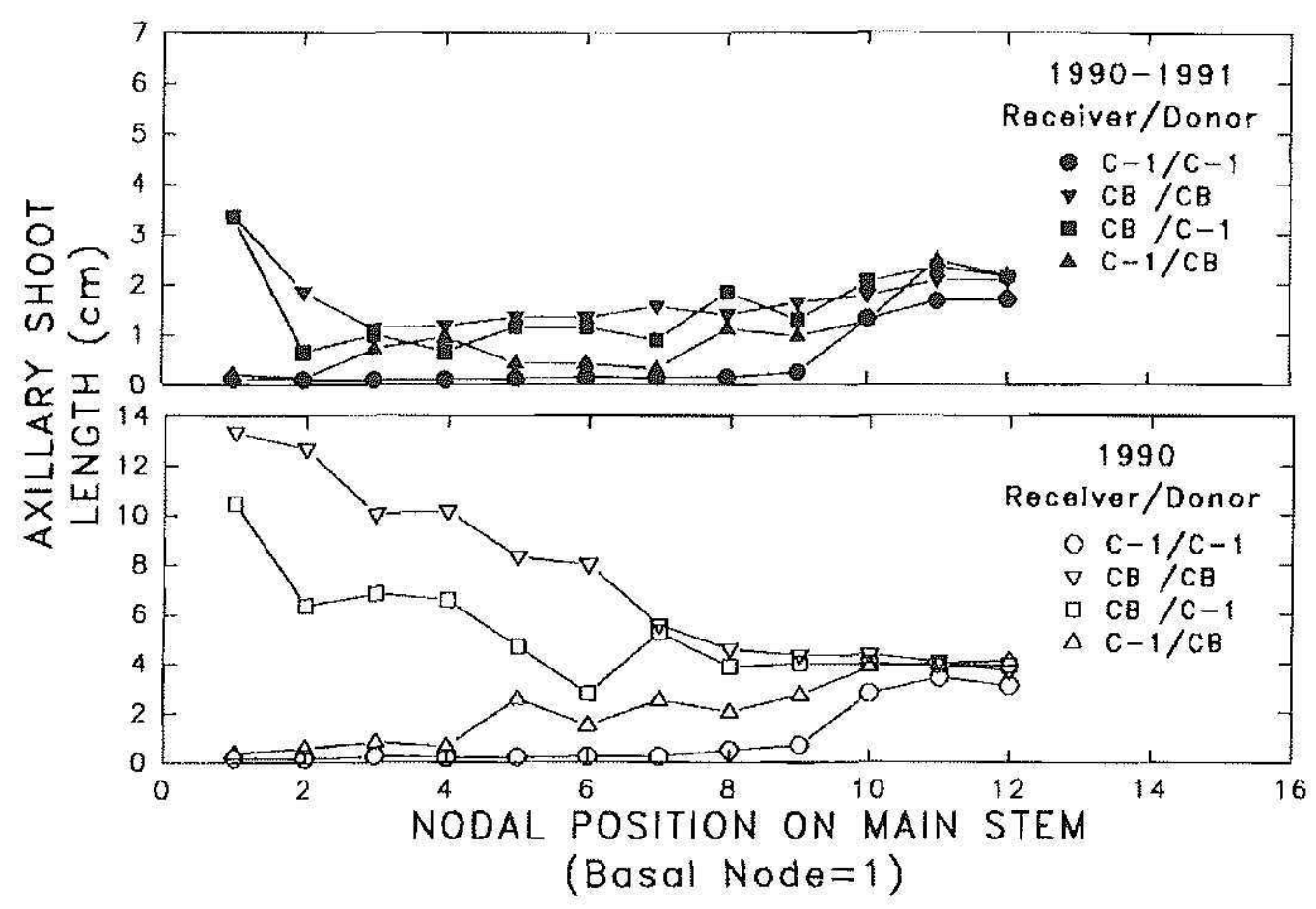

FIGURE 2. Axillary shoot length of $\mathrm{CB}$ and $\mathrm{C}-1$ poinsettia receivers after grafting on CB and C-1 donors with leaf removal in 1990 and 1990-1991. Means were an average of data from six plants.

This finding indicates that the branching agent may have been present in $\mathrm{CB}$ donor leaves and could have been moved to $\mathrm{C}-1$ receivers as soon as seven days after grafting. The results of the leaf removal experiment suggest that the branching agent may be present not only in the leaves of $\mathrm{CB}$ poinsettias but also in other parts of the plants. More experiments are needed to determine the specific role of $\mathrm{CB}$ donor leaves in the production and movement of the branching agent to $\mathrm{C}-1$ receivers.

Stem removal experiments

As in the leaf removal experiments, plants from all graft combinations showed similar axillary shoot growth from nodes 10 to 12 in 1990 , 1990-1991 and 1991 (Figures 3, 4, 5 and 6). However, nodes 4 to 9, CB/ $\mathrm{CB}$ and $\mathrm{CB} / \mathrm{C}-1$ had a pattern of decreasing axillary shoot growth as compared to $\mathrm{C}-1 / \mathrm{C}-1$ and $\mathrm{C}-1 / \mathrm{CB}$ in 1990 and 1991 (Figures 3, 4, 5 and $6)$.

C- $1 / \mathrm{CB}$ and $\mathrm{C}-1 / \mathrm{C}-1$ had similar patterns of axillary shoot growth in 1990 (Figures 3 and 4). In 1990-1991, however, C-1/CB plants had a pattern of axillary shoot growth similar to that of $\mathrm{CB} / \mathrm{C}-1$ from nodes 5 to 12 (Figures 3 and 4). Furthermore, $\mathrm{C}-1 / \mathrm{CB}$ plants had more axillary shoot nodes and longer axillary shoots than $\mathrm{C}-1 / \mathrm{C}-1$ from nodes 1 to 8 in 1991 (Figures 5 and 6). 


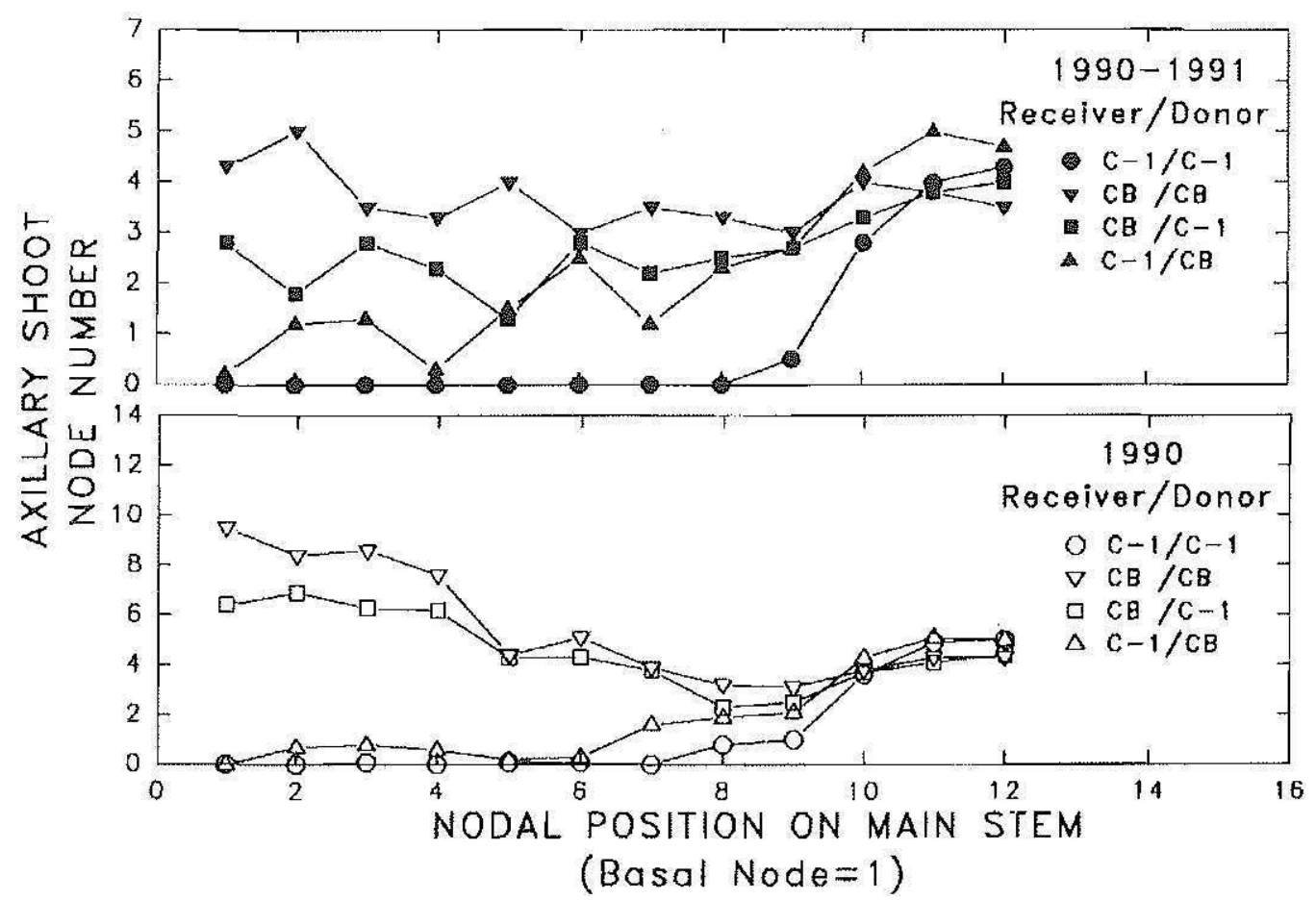

FIGURL 3. Axillary shoot node number of $\mathrm{CB}$ and $\mathrm{C}-1$ poinsettia receivers after grafting and removal of the apical and basal parts of the CB and C-1 donor in 1990 and 19901991. Means were an average of data from 10 plants in 1990 and six plants in 1990-1991.

In 1990, the apical and basal parts of CB donor stems were removed 30 days after grafting, and the branching agent was not produced or did not move from CB donors to C-1 receivers. However, in 1990-1991 and 1991 the apical and basal parts of CB donor stems were removed 15 days after grafting and production and movement of the branching agent occurred. This finding suggests the presence of an endogenous growth regulator in the apical or basal part of CB donor stems that may have prevented the production, movement or the expression of the branching agent after 15 days of grafting. Stems and other parts of CB poinsettia plants may be the source and may promote the movement of the branching agent.

Shade experiment

CB receivers with donors grown without shade had more axillary shoot nodes than $\mathrm{C}-1$ receivers with donors under shade (Table 1; Figure 7). However, $\mathrm{CB}$ receivers had longer axillary shoots than $\mathrm{C}-1$ receivers regardless of whether donors were shaded or unshaded (Table 1: Figure 8 ). The difference in axillary shoot nodes between $\mathrm{C}-1$ receivers (donors shaded) and $\mathrm{CB}$ receivers (donors unshaded) caused a receiver $\times$ shade interaction (Table 1 ; Figure 7 ). 


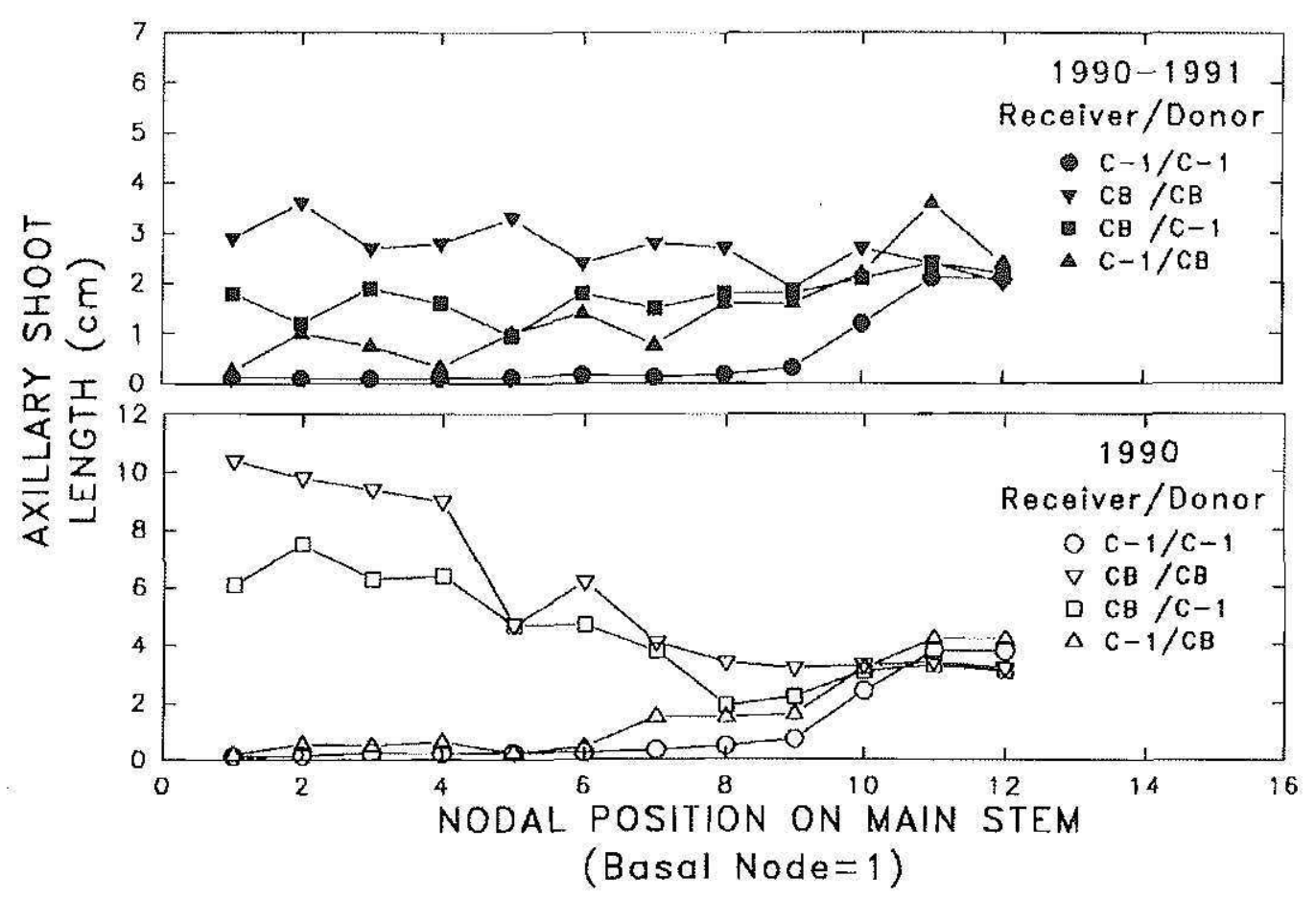

Figune 4. Axillary shoot length of $\mathrm{CB}$ and $\mathrm{C}-1$ poinsettia receivers after grafting and removal of the apical and basal parts of the CB and C- 1 donor in 1990 and 1990-1991. Means were an average of data from 10 plants in 1990 and six plants in 1990-1991.

C-1 and CB receivers with donors under shade had slightly fewer axillary shoot nodes than $\mathrm{C}-1$ and $\mathrm{CB}$ receivers with donors unshaded (Figure 7). Photosynthates produced in the unshaded receiver plants may have moved to the shaded donor plants, a factor which may have partially reduced photosynthate level of the receiver plants. Reduced photosynthates in receiver plants with shaded donor plants may have caused the reduction in growth compared to growth when the donors were unshaded (Figure 8).

Even though there was no significant main effect of $\mathrm{CB}$ and $\mathrm{C}-1$. as donors, $\mathrm{CB}$ donors (unshaded) partially increased $\mathrm{C}-1$ receiver axillary shoot growth above node 3 as compared to $\mathrm{C}-1 / \mathrm{C}-1$ (unshaded) (Figures 7 and 8). Also, $\mathrm{CB}$ donors (shaded) slightly increased the length of $\mathrm{C}-1$ receivers' axillary shoots and number of axillary shoot nodes above node 4 as compared to $\mathrm{C}-1 / \mathrm{C}-1$ (shaded) (Figures 7 and 8 ). The lack of significant differences in $\mathrm{C}-1 / \mathrm{CB}$ axillary shoot growth below node 5 precluded the demonstration of a significant main effect of $\mathrm{CB}$ as a donor in the production and movement of the branching agent. Shading CB donor leaves and stems did not prevent the production and movement of the branching agent to $\mathrm{C}-1$ receivers. 


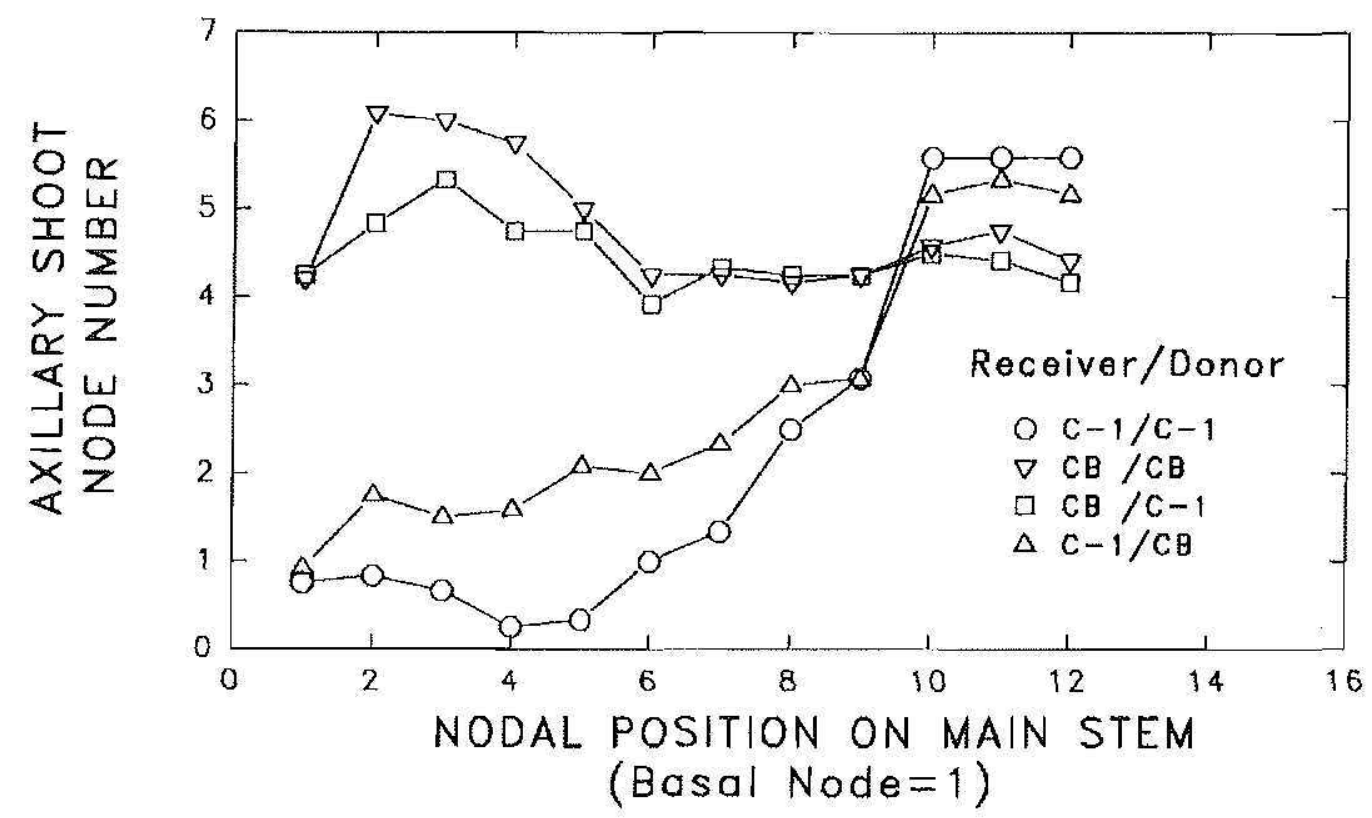

FIGI'RE 5. Axillary shoot node number of $C B$ and $C-1$ poinsettia receivers after grafting and removal of the apical and basal parts of the CB and C-1 donor, Noble Center Growth Chambers, OSU in 1991. Means were an average of data from 12 plants.

If $\mathrm{CB}$ donors had been changed to a sink by shading, and no movement of the branching agent to C-1 receivers had occurred, that would have shown that a source-sink relation was necessary for the production and movement of the branching agent. However, the amount of shade under which CB donors grew may have caused CB donors to be only partially dependent on C-1 receivers. CB donor leaves grown under shade were green and thus were able to produce photosynthates. We cannot conclude from the results of this experiment that the production and movement of the branching agent depends only on a source-sink relationship.

Environmental factors such as light, temperature, inorganic nutrients and water may have affected the production and movement of the branching agent between $\mathrm{CB}$ donors and $\mathrm{C}-1$ receivers and thus may have caused the variation in branching between years. Light intensity and duration during $\mathrm{C}-1$ and $\mathrm{CB}$ poinsettia growth may have adversely affected the production and movement of the branching agent from $\mathrm{CB}$ donors to C-1 receivers. The light intensity in the greenhouse was reduced by a black polypropylene shade used to reduce temperature during the summer and by yellowing of the fiberglass-reinforced plastic glazing. Reduced light intensity in combination with high nitrogen levels is known to increase apical dominance in Linum usitatissimun L. cv. Redwing (Gregory and Veale, 1957). C-1. receiver plants grafted on CB 


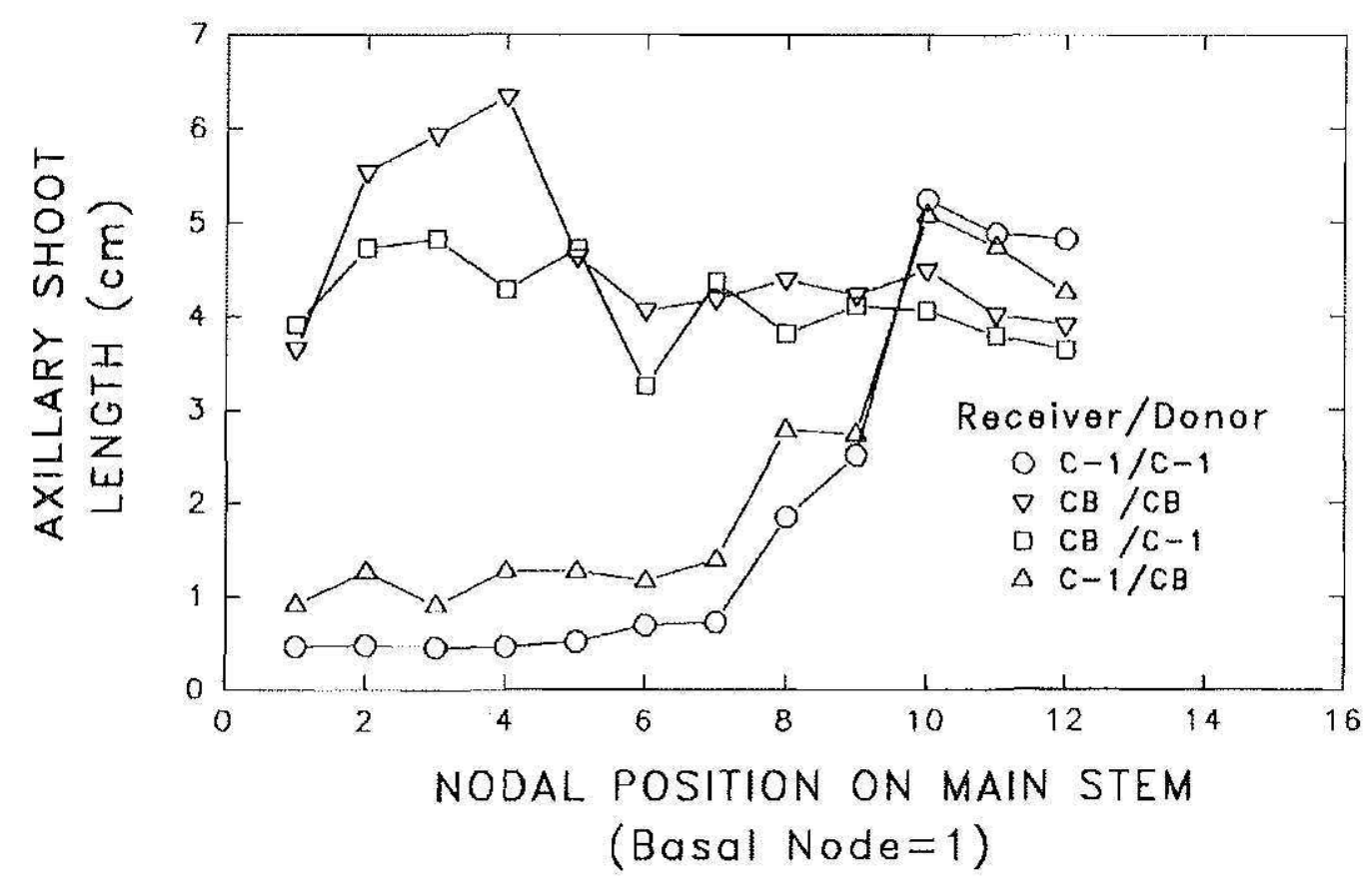

FrGURE 6. Axillary shoot length or $\mathrm{CB}$ and $\mathrm{C}-1$ poinsettia receivers after grafting and removal of the apical and basal parts of the CB and C-1 donor, Noble Center Growth Chambers, OSU in 1991. Means were an average of data from 12 plants.

donors may have had strong apical dominance because of a reduced light intensity in the greenhouse, thus limiting the production, movement or expression of the branching agent.

C-1 receivers and $C B$ donors were grown under $L D$, which favors apical dominance in photoperiodically-sensitive species (Phillips, 1969). Production and movement of the branching agent from $\mathrm{CB}$ donors to $\mathrm{C}-1$ receivers may have been adversely affected by $\mathrm{LD}$. Also, $\mathrm{C}-$ 1 apical dominance may have been increased and CB branching capacity reducing by $L D$, thereby limiting the expression of the branching agent.

Air temperature was above the threshold $\left(21^{\circ} / 29^{\circ} \mathrm{C}\right.$ day/night) for optimum vegetative poinsettia growth (Ecke et al., 1990) from July to September in 1990, 1991 and 1992. High temperatures are known to reduce the branching capacity in free-branching poinsettias (Dole and Wilkins, 1991). Production and movement of the branching agent from CB poinsettia donors may have been adversely affected by air temperatures from July to September in 1990, 1991 and 1992.

In the 1990-1991 experiments, C-1 and CB poinsettia donors and receivers had salt toxicity symptoms. Increased soil salinity may have reduced the water availability to the plants and may have reduced the branching pattern of $\mathrm{C}-1$ receivers on $\mathrm{CB}$ donors. Apical meristems of 
TABLE 1.-Axillary shoot growth of $C B$ and $C-1$ poinsettia receivers after grafting on $C B$ and C-1 donors with or without shade in 1991-1.992.

\begin{tabular}{llcc} 
& & \multicolumn{2}{c}{ Axillary shoot } \\
\cline { 3 - 4 } Factors & Shade & Number of nodes' & Length (mm) \\
\hline Receiver & yes & $1.8 \mathrm{a}$ & \\
$\mathrm{C}-1$ & yes & $4.6 \mathrm{ab}$ & $73 \mathrm{a}$ \\
$\mathrm{CB}$ & no & $3.2 \mathrm{ab}$ & $28 \mathrm{a}$ \\
$\mathrm{C}-1$ & no & $7.1 \mathrm{~b}$ & $106 \mathrm{~b}$ \\
$\mathrm{CB}$ & & & \\
\hline
\end{tabular}

'Means followed by the same letter do not differ by LSD, $P=0.05$.

C-1, with a strong apical dominance, may have competed for the available water with the axillary buds reducing the water and nutrients available for the axillary shoot growth. Axillary bud growth in Helianthus annuus L., Phaseolus vulgaris L. and Pisum sativum L. has been promoted by water availability and high humidity, indicating that competition for water may play a critical role in apical dominance (McIntyre, 1977).

Both stems and leaves of $\mathrm{CB}$ poinsettia donors may produce and promote the movement of the branching agent to $\mathrm{C}-1$ receivers by influencing the movement of endogenous hormones between $\mathrm{CB}$ and $\mathrm{C}-1$.

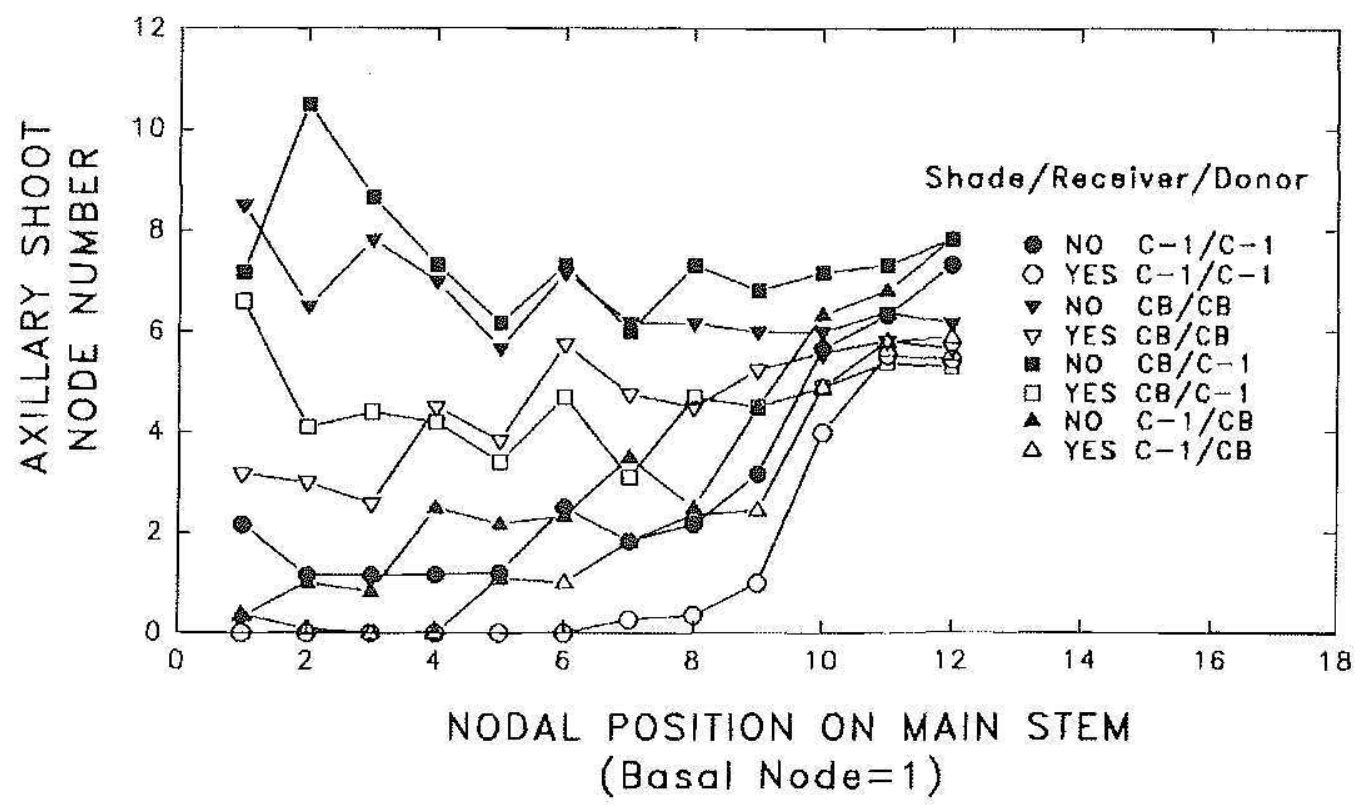

FIGURE 7. Axillary shoot node number of $\mathrm{CB}$ and $\mathrm{C}-1$ poinsettia receivers after grafting on CB and C-1 donors with (Yes) and without (No) shade in 1991-1992. Means were an average of data from 12 plants. 


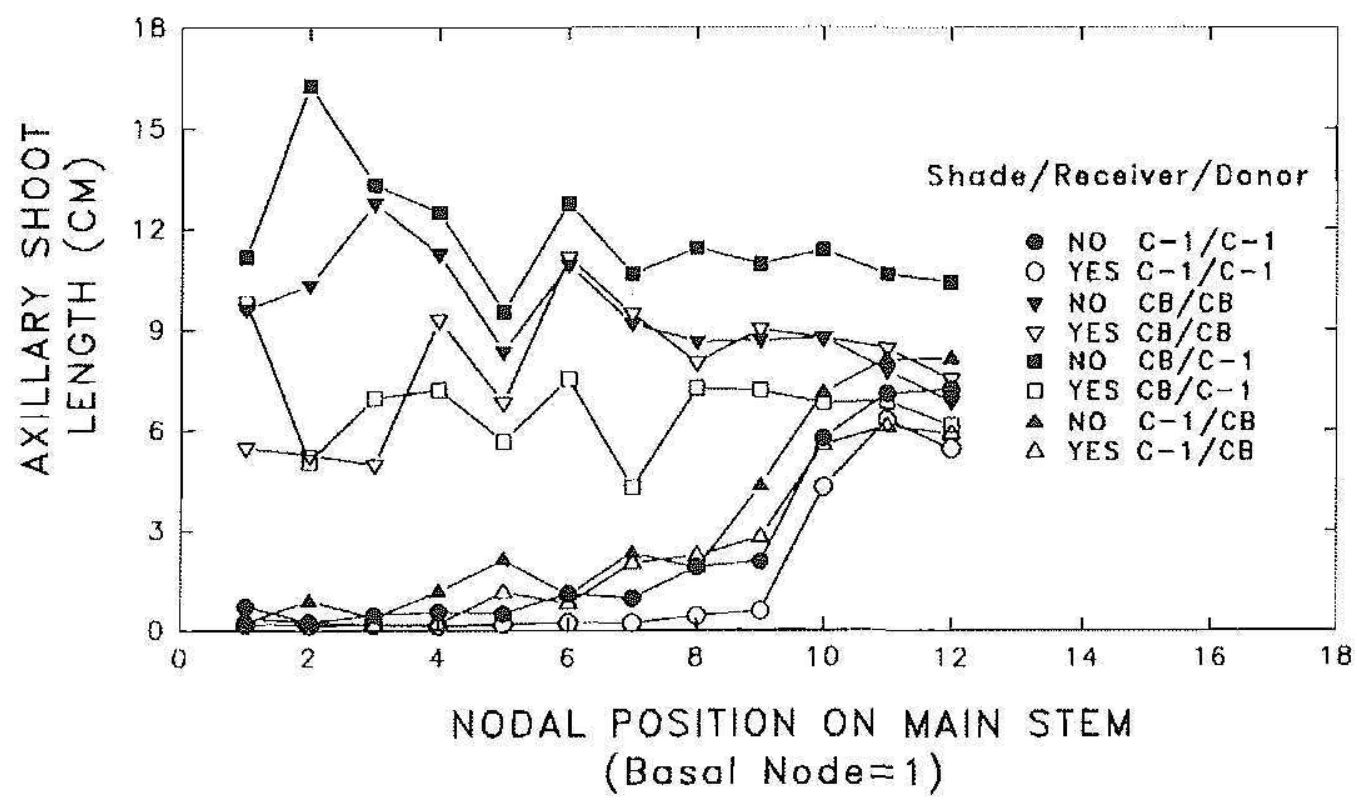

FIGURE 8, Axillary shoot length of $\mathrm{CB}$ and $\mathrm{C}-1$ poinsettia receivers after grafting on $\mathrm{CB}$ and C-1 donors with (Yes) and without (No) shade in 1991-1992. Means were an average of data from 12 plants.

Leaves, buds and the shoot apex may modify apical dominance by influencing the movement of endogenous hormones (Hillman, 1970). An increase in the ratio of endogenous cytokinin in $\mathrm{C}-1$ plants to endogenous auxin may have released $\mathrm{C}-1$ shoots from apical dominance, resulting in emergence of lateral buds (Bidwell, 1991). Furthermore, cytokinins (Sachs and Thimann, 1964; Williams and Stahly, 1968), and auxin-antagonists like 2,3,5-triiodobenzoic acid (Ansen and Hamner, 1953) have increased axillary shoot branching in other plant species.

\section{LITERATURE CITED}

Ansen, S. and C. L. Hamner, 1953. Effect of growth regulating compounds on the development of basal shoots of greenhouse roses. Bot. Gaz. 115:86-89.

Beeson, R. C., Jx. and W. M. Proebsting, 1988. Photosynthate translocation during union development in Picea grafts. Can. J. For: Res. 18(8):986-990.

Bidwell, R. G. S., 1991. Plant physiology a treatise. Vol X. Growth and development. Academic Press Inc., San Diego, CA.

Craft-Brander, S. J., T. G. Sutton and J. L. Sims, 1988. Influences of leaf grafting on leaf constituents and senescence characteristics of burley and flue-cured tobacco. Crop Sci. 28(2):269-274.

Dole, J. M. and H. F. Willsins, 1992. In vivo characterization of a graft transmissable, free-branching agent in poinsettia. J. Amer. Soc. Hort. Sci. 117(6):972-975.

Dole, J. M. and H. F. Wilkins, 1991. Vegetative and reproductive characteristics of poinsettia altered by a graft transmissable agent. d. Amer. Soc. Hort. Sci. 116(2):307311. 
Ecke, P., O. A. Matkin and D. E. Hartley, 1990. The poinsettia manual. 3rd ed. Paul Ecke Poinsettias, Encinitas, CA.

Gregory, F. G. and I. A. Veale, 1957. A reassessment of the problems of apical dominance. Symp. Soc. Biol. 11:1-20.

Hartmann, H. T., D. E. Kester and F. T. Davis, Jr., 1990. Plant propagation-principles and practices, 5th ed. Prentice Hall, Inc. Englewood Cliffs, N.J.

Hillman, J., 1970. The hormonal regulation of bud outgrowth in Phaseolus vulgaris L. Planla 90(3):222-229.

McIntyre, G. I., 1977. The role of nutrition in apical dominance p. 251-273. In: D. H. Jermings (ed.). The society for experimental biology symposium 31. Cambridge University Press, London.

Phillips, Y. D. J., 1969. Apical dominance. p. 165-202. In: M. B. Wilkins (ed.). The physiology of plant growth and development, McGraw-Hjll, London.

Sachs, T and K. V. Thimann, 1964. Release of lateral buds from apical dominance. $\mathrm{Na}$ ture 201(4922):939-940.

Stimart, D. P, 1983. Promotion and intibition of branching in poinsettia in grafts between self-branching and non-branching cultivars. J. Amer. Soc. Hort. Sci. 108(3):419-422.

Tai, G. C. C., R. H. Coffin and R. Y. Yada, 1988. The effect of scion and stock autografting and heterografting on specific gravity, sugar content and chip color of potatoes. Amer: Potato J. 65(3):141-145.

Williams, M. W. and E. A. Stahly, 1968. Effect of cytokinins on apple shoot development from axillary buds. HortScience 3(2):68-69. 